\title{
Penile cutaneous horn-a rare case
}

\author{
Barolia $\mathrm{DK}^{1 *}$, Sethi $\mathrm{D}^{2}$, Sethi $\mathrm{A}^{3}, \operatorname{Ram}^{4}$, Meena $\mathrm{S}^{5}$, Rachhoya $\mathrm{P}^{6}$ \\ Dr Dinesh Kumar Barolia ${ }^{*}$, Dr Deepak Sethi ${ }^{2}$, Dr Anjali Sethi ${ }^{3}$, Dr Jamana Ram ${ }^{4}$, Dr Shanker Meena ${ }^{5}$, Dr Pinky \\ Rachhoya $^{6}$
}

$\mathbf{1 , 2 , 4 5}^{\mathbf{2}}$ Department of General Surgery, R.N.T. Medical College, M.B. Government Hospital, Udaipur, Rajasthan, India. ${ }^{3}$ Department of General Surgery, Pacific Medical College and Hospital, Udaipur, Rajasthan, India 313001. ${ }^{6}$ Department of Obstetrics and Gynecology, R.N.T. Medical College, M.B. Govt. Hospital, Udaipur, Rajasthan, India

Address for Correspondence: Dr Dinesh Kumar Barolia, Email: dbaroliarnt@gmail.com

\begin{abstract}
Penile cutaneous horn is a horn like hyper-keratotic lesion over penis which is an unusual site and a rare case. We report a case of cutaneous horn of penis in age of 20 years which is also a rare presentation in this age group.
\end{abstract}

Key words:Cutaneous Horn, Penile Cutaneous Horn, Penile Horn.

\section{Introduction}

Cutaneous horns are also known as cornucutaneum, which are unusual keratinous skin tumors with the appearance of horn. This is clinically appears as conical projection above the surface of the skin [1]. Although the cutaneous horn may develop over a normal skin, these more often develop over some pre-existing skin conditions like warts, keratosis, nevi, trauma, burns, lupus vulgaris, and even on an epithelioma[2]. Cornucutaneum (cutaneous horn) is a well-defined cone-shaped lesion with hyper-keratotic features. This type of lesion mostly found on exposed skin [3]. Cutaneous horns occur rarely on the penis. The incidence of the lesion is very low, with only 30 cases reported in 25 years [4]. Disease may be benign in $42 \%-56 \%$, premalignant in $22 \%-37 \%$, or frankly malignant in $20 \%-22 \%$ of patients [5].

\section{Case Report}

We report a case of cutaneous horn at unusual site over penis. A twenty one year old male presented in hospital with conical shape hard swelling over ventral surface of penis. He noticed the lesion one year back. Before one year he was having the complaint of phimosis. Therefore he was operated circumcision. After two months of circumcision he develops the lesion. The lesion was gradually increased in size. When he came to hospital, lesion was conical in shape, hard in consistency, over ventral surface of penis and near

Manuscript Received: $20^{\text {th }}$ Sept 2015

Reviewed: $4^{\text {th }}$ Oct 2015

Author Corrected: $10^{\text {th }}$ Oct 2015

Accepted for Publication: $14^{\text {th }}$ Oct 2015 about three centimeter in size. Horn was surgically excised with free margine. Histopathology of tissue at base of cutaneous horn shows hyperplastic squamous epithelium with marked hyper keratosis. There was no evidence of malignancy. This patient discharged without any complication with satisfactory result. In follow up patient was satisfied with surgery and having no complain.

\section{Discussion}

Cutaneous horn (synonyms; Cornucutaneum: Cornuhumanum) is a conical, hyper-keratotic protrusion that often resembles like an animal horn. The term "cutaneous horn" is not a true diagnosis. It is named after morphologic appearance like animal horn. To this date just $>150$ cases have been reported in the literature [4].The factor which leads to these patients developing penile horn is unclear. The roles of chronic irritation, phimosis, surgical trauma and radiotherapy that have been implicated in penile horn formation have also been found to predispose to carcinoma penis [1,6]. Cutaneous horn may be benign, premalignant or malignant. The etiology of penile cutaneous horn remains uncertain. The earliest documented case of cutaneous horn, or cornucutaneum, of an elderly Welsh woman in London who was displayed commercially as an anomaly of nature in 1588 [6]. The first case report of penile cutaneous horn was published in 1854[7]. The European Association of Urology guidelines on penile cancer they consider penile cutaneous horn as a premalignant lesion and approximately one-third of 
penile cutaneous horns are associated with an underlying malignancy[8,9].

Recently, several studies indicated that immunehistochemical expression of p16ink4a may be used not only as a marker of high-risk HPV infection, but also on differential diagnosis of penile epithelial abnormalities and precancerous lesions. Earlier data showed strong association of HPV with high-grade squamous cell carcinoma, whereas well-differentiated SCC subtypes were not HPVrelated. Chaux et al. Have published a study designed to seek an immune-histochemical profile that can be helpful in the classification and differential diagnosis of penile epithelial abnormalities and precancerous lesions[10].

\section{Conclusion}

Penile cutaneous horn is a rare case.Penile cutaneoushorn is a clinical diagnosis which is made on the basis of morphological appearance. Horn can be associated with benign or malignant condition. True diagnosis is proved after histopathological examination of tissue. We report this case of penile cutaneous horn with benign histopathology.
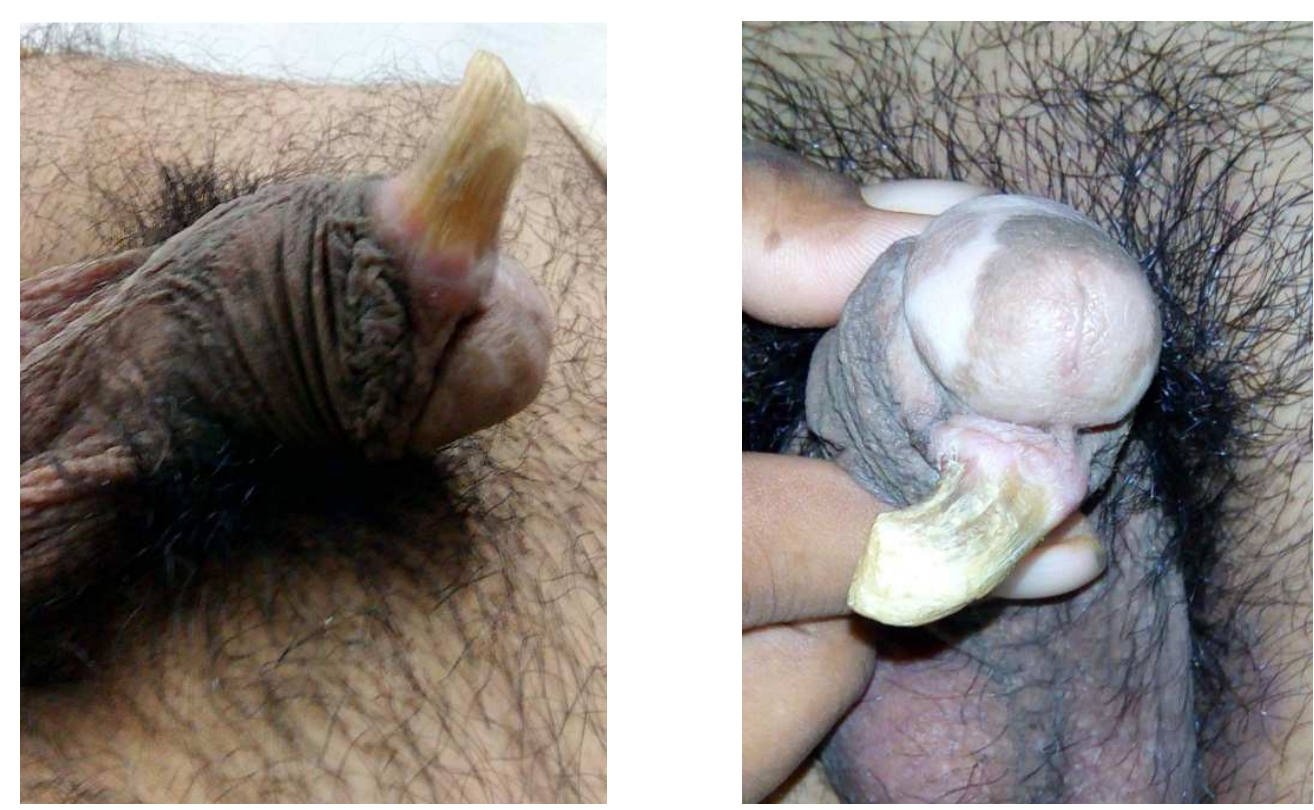

Fig 1 and 2: showing penile cutaneous horn around $3 \mathrm{~cm}$ in length

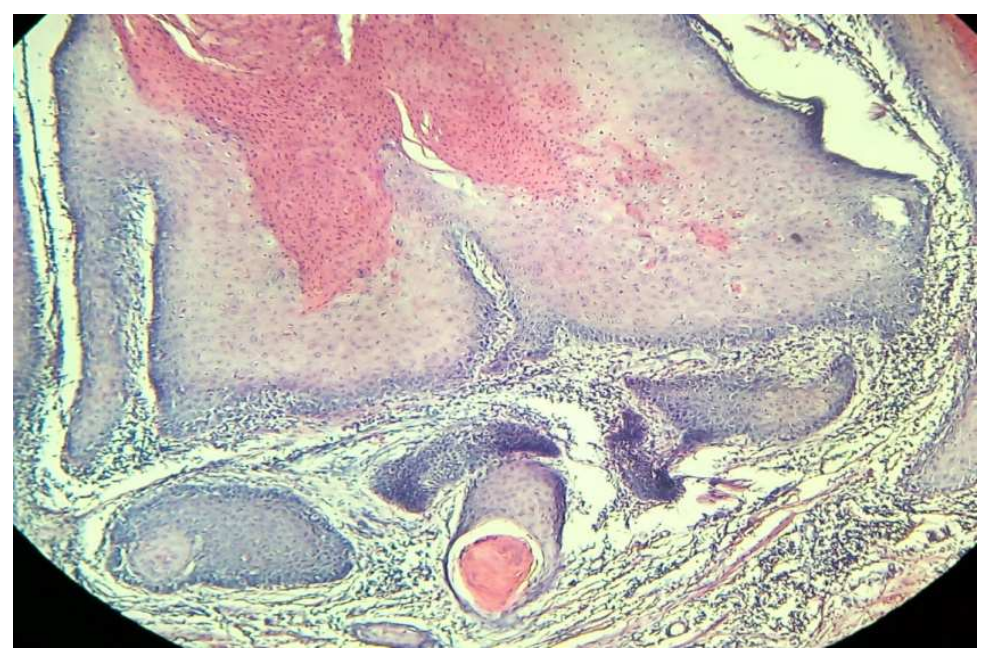

Fig 3:Histopathological slide at base of penile cutaneous horn-showing hyperplastic squamous epithelium, keratin pearl with chronic inflammatory infiltration.(10X) 


\section{References}

1. Copcu E, Sivrioglu N, Culhaci N. Cutaneous horns: are these lesions as innocent as they seem to be? World J Surg Oncol. 2004 Jun 3;2:18.

2. Rubin MA, Kleter B, Zhou M, Ayala G, Cubilla AL, Quint WG, Pirog EC. Detection and typing of human papillomavirus DNA in penile carcinoma: evidence for multiple independent pathways of penile carcinogenesis.Am J Pathol. 2001 Oct;159(4):1211-8.

3. Lever FW, Schaumburg LG. Histopathology of the skin. 6th Ed, New York: JB Lippincott Co.; 1984.

4. Karthikeyan, Thappa DM, Jaisankar TJ, Balamourougane, Ananthakrishnan N, Ratnakar C. Cutaneous horn of glans penis. Sex Transm Infect. 1998 Dec;74(6):456-7.

5. Lowe FC, McCullough AR. Cutaneous horns of the penis: an approach to management. Case report and review of the literature. J Am Acad Dermatol. 1985 Aug;13(2 Pt 2):369-73.

6. Bondeson J. Everard Home, John Hunter, and cutaneous horns: a historical review. Am J Dermatopathol. 2001 Aug;23(4):362-9.
7. Jewett PA. A case of horn on the glans penis. Med Times. 1854;3:9.

8. Pizzocaro G, Algaba F, Horenblas S, Solsona E, Tana S, Van Der Poel H, Watkin NA; European Association of Urology (EAU) Guidelines Group on Penile Cancer. EAU penile cancer guidelines 2009. Eur Urol. 2010 Jun;57(6):1002-12. doi: 10.1016/j.eururo.2010.01.039. Epub 2010 Feb 4.

9. Rosen RC, Cappelleri JC, Smith MD, Lipsky J, Peña BM. Development and evaluation of an abridged, 5item version of the International Index of Erectile Function (IIEF-5) as a diagnostic tool for erectile dysfunction.Int $\mathrm{J}$ Impot Res. 1999 Dec;11(6):319-26.

10. Chaux A, Pfannl R, Rodríguez IM, Barreto JE, Velazquez EF, Lezcano C, Piris A, Netto GJ, Cubilla AL. Distinctive immunohistochemical profile of penile intraepithelial lesions: a study of 74 cases. Am J Surg Pathol. 2011 Apr;35(4):553-62. doi: 10.1097/PAS.0b013e3182113402.

\section{How to cite this article?}

Barolia DK, Sethi D, Sethi A, Ram J, Meena S, Rachhoya P. Penile cutaneous horn-a rare case. Int J Med Res Rev 2015;3(9):1102-1104. doi: 10.17511/ijmrr.2015.i9.201. 